\title{
V bludišti jménem Alzheimer: Na co v ordinaci nezbývá čas
}

Kateřina Čechová, Adéla Fendrych Mazancová a Hana Marková (eds.)

Praha: Management Press, 2019. 430 s.

Název knihy vystihuje trefně problematiku, které se věnuje. Př́ičiny Alzheimerovy nemoci a její léčba se hledá, systém péče, kde se nutně překrývá sféra zdravotní a sociální, je složitý a není snadné se v něm zorientovat a umět využít jeho možnosti, které jsou neznalému skryté. Pacient se ztrácí ve světě venku a nakonec i uvnitř sebe, ztrácí se i svému okolí, a to fakticky, když zabloudí, i pomyslně, když přestává být sám sebou. Podobné platí i pro pečující, již hledají nové způsoby vztahu s člověkem, který přestává být tím, koho znali, ke komu možná i vzhlíželi. Mohou se cítit opuštěni a nevidí cestu ven. Alzheimerova nemoc je bludištěm, kterým hledá cestu jedinec i společnost. Čtyři části, jedenáct kapitol, 430 stránek předkládané publikace pak nabízí čtenáři vedení tímto bludištěm prostřednictvím aktuálních poznatků a ucelených informací.

Publikace vznikla po impulzu ze strany Albatros Media na základě spolupráce editorek s Alzheimer nadačním fondem (ANF), jehož byly všechny tři v nedávných letech stipendistky. $\mathrm{V}$ rámci těchto stipendií měly př́ležitost absolvovat dlouhodobé stáže na prestižních pracovištích v zahraničí, kde prokázaly nejen hluboké znalosti, ale i angažovanost v problematice. Proto se na ně s důvěrou obrátila ředitelka ANF, Šárka Kovandová, s poptávkou nakladatelství. Editorky oslovily se svým záměrem kolegyně a kolegy ze svého profesního okolí a tato spolupráce 14 odborníků z řad psychologů, lékařů, sociálních pracovnic a architektky po dvou letech dospěla v červenci 2019 k vydání populárně naučné knihy v nakladatelství Media Press patřící pod Albatros Media. Odbornými korekturami k výsledku přispěli přední čeští neurovědci Ondřej Bezdíček, Daniel Hudeček a Robert Rusina. Nakladatelství a autorský tým vyjadřují podporu činnosti ANF tím, že 50 Kč z každé prodané knihy putuje na jeho konto a bude sloužit $\mathrm{k}$ podpoře dalších mladých vědců snažících se o řešení otázek spojených s touto nemocí.

V první části se ve třech kapitolách věnují editorky v roli autorek popisu normálního stárnutí, stádia mírné kognitivní poruchy a demence, neuropsychologickým i dalším vyšetřením relevantním pro tato období či stavy a seznamují čtenáře i se změnami v mozku, ke kterým v nich dochází. Autorky věnovaly péči tomu, aby informace podávaly formou co nejvíce srozumitelnou široké veřejnosti. Součástí textu jsou konkrétní životní př́iběhy, jež názorně ilustrují teoretický výklad.

Č́st druhá ve čtyřech kapitolách uvádí současné možnosti léčby různých druhů symptomů tělesných i duševních, a to farmakologické i nefarmakologické, psychoterapeutických a podpůrných př́stupů. Neurologové Jiř́i Cerman a Ondřej Lerch zařadili do kapitoly o farmakologických prŕístupech vedle léčiv i doplňky stravy, které nabyly velké popularity, a uvádějí na pravou míru některá laická přesvědčení. Obzvláště kapitola nefarmakologické léčby neurovědců Kateřiny Sheardové a Rastislava Šumce, která předkládá čtenáři tipy k úpravě 
životního stylu, bude velmi užitečná pro každého čtenáře, nebot' jde o univerzální pravidla primární prevence chronických neinfekčních onemocnění, tj. civilizačních chorob. Psychoterapeutická kapitola psycholožky Terezy Makové a kapitoly o podpůrných opatření terapeutky Jitky Andresové seznamují se světem psychologie a psychoterapie. Pomohou se zorientovat i člověku, který s těmito obory nikdy neměl př́ležitost či potřebu být v kontaktu. Zabývají se pacientem i pečující osobou.

Třetí část je věnována praktickým tipům. Nejprve architektka Anežka Příhodová poskytne vodítka k úpravě domova tak, aby byl bezpečnější a bylo tak možné delší setrvání člověka $\mathrm{s}$ demencí $\mathrm{v}$ domácím prostředí. Poté následují další velmi praktické informace sloužící k orientaci v sociálním systému České republiky od Sáry Babej a Lucie Dostalové. Právník Vojtěch Růžička osvětluje základy práva a situace, kdy člověk pozbývá schopnosti sám rozhodovat. Čtenář má př́ležitost osvojit si základní pojmy, se kterými se střetne při jednání se státem, a to při řešení svéprávnosti, plné moci, předem vysloveného přání či závěti.

Poslední čtvrtá část se zabývá závěrečným obdobím života člověka trpícího demencí a paliativní péčí. Geriatrička Hana Vaňková opět dbá na to, aby provedla čtenáře odpověd’mi na otázky, které by každý pečující mohl o tomto těžkém období mít.

Kniha je přehledně členěna, a i když se čtenář neodhodlá ji číst celou od začátku do konce, i její jednotlivé části mu přinesou poučení. V blocích na červeném pozadí jsou zvýrazněny body, které autoři považují za nejpodstatnější. Kniha obsahuje i výkladový slovník vybraných pojmů, seznam použité literatury a rejstř́k. Svou obsahovou bohatostí a aktuálností tato publikace zaujme všechny pomáhající profese. Rodinám, kde někdo Alzheimerovou nemocí trpí, přinese mnohá vysvětlení a pomůže jim s praktickou péčí o blízkého nemocného i o sebe. Vzhledem k tomu, že dosud není znám lék, který by Alzheimerovu nemoc dokázal zastavit, těžko doporučit člověku, kterému byla diagnóza stanovena, aby si četl v publikaci, kde jsou i informace, které ho mohou silně rozrušit. Nicméně, rady k úpravě životního stylu mohou mít povzbuzující účinek, a to především, pokud jsou pak realizovány. Přestože je text místy dosti odborný, a proto i méně srozumitelný pro lidi z nelékařských oborů, naprostá většina textu je velmi př́stupná, přehledná a praktická pro širokou veřejnost.

Ráda bych na závěr poděkovala celému autorskému týmu, Alzheimer nadačnímu fondu i nakladatelství Albatros Media za tuto publikaci, která se jistě stane v nejbližších letech jednou z nejvyhledávanějších v souvislosti s péčí o lidi s Alzheimerovou nemocí.

\section{Hana Georgi}

ČMPS, z.s.

hanageorgi.cz@gmail.com

Leden 2020

Georgi, H. (2020). V bludišti jménem Alzheimer: Na co v ordinaci nezbývá čas [recenze].

E-psychologie, 14(1), 73-74. https://doi.org./10.29364/epsy.368 